\title{
Selective Serotonin Reuptake Inhibitors Decrease Impulsive Behavior as Measured by an Adjusting Delay Procedure in the Pigeon
}

\author{
Mary C. Wolff, M.A., and J. David Leander, Ph.D.
}

The inability to delay gratification (reinforcement or reward) is one index of impulsive behavior. In order to measure the willingness of pigeons to delay reinforcement, an adjustable delay schedule was developed that allowed daily approximations of an indifference point between immediate brief access to reinforcer and delayed, longer access to reinforcer. Acute administration of the anxiolytic alprazolam $(5 \mathrm{mg} / \mathrm{kg})$ decreased the length of delay tolerated before a larger reinforcement. Likewise, acute administration of the anxiolytic chlordiazepoxide $(10 \mathrm{mg} /$ $\mathrm{kg}$ ) produced a similar, although not significant, effect.

Neither acute nor five daily injections of 8-OH-DPAT, a 5$\mathrm{HT}_{1 \mathrm{~A}}$ agonist, or WAY100635, a 5-HT $\mathrm{T}_{1 \mathrm{~A}}$ antagonist, affected the length of the delay period. Chronic (17 day), but not acute injections of the selective serotonin reuptake inhibitors (SSRIs) fluoxetine (10 $\mathrm{mg} / \mathrm{kg}$ ), citalopram (10 $\mathrm{mg} / \mathrm{kg}$ ) and paroxetine $(3 \mathrm{mg} / \mathrm{kg}$ ) increased the delay period. When given in addition to $1 \mathrm{mg} / \mathrm{kg}$ of $8-\mathrm{OH}-\mathrm{DPAT}$, but not $1 \mathrm{mg} / \mathrm{kg}$ WAY100635, the effect of fluoxetine was accelerated in that the increase in delay was observed earlier in the treatment. These data support the use of SSRIs to decrease impulsive behavior. Addition of a $5-H T_{1 A}$ agonist, but not a 5-HT $T_{1 A}$ antagonist, to the SSRI may hasten the therapeutic activity of the SSRI in treating impulsivity.

[Neuropsychopharmacology 27:421-429, 2002]

(C) 2002 American College of Neuropsychopharmacology. Published by Elsevier Science Inc.
KEY WORDS: SSRI; 5-HT1A agonist; 5-HT1A antagonist; Impulsive behavior; Pigeon

Relatively impulsive behavior is characterized by a number of different factors, such as an inability to withhold a response or an inability to delay gratification (Evenden 1999). Impulsiveness is a component of many behavioral problems such as aggression, suicide, and

From the Lilly Research Laboratories, Eli Lilly and Company, Indianapolis, IN 46285, USA.

Address correspondence to: Mary Wolff, Lilly Research Laboratories, Eli Lilly and Company, Mail Code No. 0510, Lilly Corporate Center, Indianapolis, IN 46285. Tel.: (317) 276-8148; Fax: (317) 2765546; E-mail: wolff_mary_c@lilly.com

Received December 14, 2000; revised September 12, 2001; accepted December 6, 2001.

Online publication: $2 / 7 / 02$ at www.acnp.org/citations/ Npp020702241. drug and alcohol abuse. Clinical evidence suggests that the serotonin (5-hydroxytryptamine (5-HT)) system has an important role in the regulation of impulsive behavior (review: Brunner and Hen 1997). For instance, there is an inverse correlation between central 5-HT concentration (as measured by the cerebral spinal fluid 5-hydroxyindoleacetic acid (5-HIAA) levels) and impulsive violent behavior (Linnoila et al. 1983). There is also a correlation between decreased ${ }^{3} \mathrm{H}$-imipramine binding and pathologically impulsive behaviors (review: Soubrie 1986; Roy et al. 1988). Conversely, SSRIs are reported to have beneficial effects on impulsive behaviors (Kavoussi et al. 1994).

In the laboratory, impulsive behavior may be operationally defined as the choice of a small immediate reward over a larger delayed reward (Ainslie 1974; Logue 1988). Neuropharmacological manipulations that affect the concentration of 5-HT in the brain modify the effec- 
tiveness of a reward when its delivery is delayed (Soubrie 1986). For example, administration of 5-HT reuptake inhibitors increased responding for a delayed reward (Thiebot et al. 1985), whereas lesions of the 5-HT system decreased the willingness of rats to respond for a delayed reward (Wogar et al. 1993).

The following study is a modification of an adjusting delay procedure (Mazur 1984, 1995; Wogar et al. 1993), in which the subject was allowed to choose between two alternatives, a smaller immediate reward and a larger delayed reward. In the present study, the delay to the offering of the larger reinforcement was adjusted from a standard daily starting value depending upon the pigeon's response. If the pigeon chose the smaller reinforcement, the delay until the larger reinforcement decreased, but if the pigeon chose the larger reinforcement, the delay was increased. The delay to the smaller reinforcement remained constant throughout the experiment. The magnitude of the reinforcement (a mixed grain food reward) was controlled by the length of time that the grain was available to be eaten. The average amount of delay until the larger reinforcement on the last five blocks of trials of each day was recorded. This value was taken as an approximation of an indifference point, or a point at which one alternative was not preferred over the other. If the responses of the pigeon were such that the delay to the larger reinforcement was relatively short at the end of the day's session, then that behavior was taken to be relatively impulsive. On the other hand, if the delay to the larger reinforcement was relatively long, then that behavior was taken to indicate relative self-control.

The effects of increasing doses of two benzodiazepine anxiolytics (chlordiazepoxide and alprazolam), a $5-\mathrm{HT}_{1 \mathrm{~A}}$ agonist, 8-OH-DPAT (8-hydroxy-(2-di-n-propylamino) tetralin hydrobromide), a 5- $\mathrm{HT}_{1 \mathrm{~A}}$ antagonist, WAY100635 (N-\{2-[4-(2-methoxyphenyl)-1-piperazinyl]ethyl\}-N-(2-pyridinyl)cyclohexanecarboxamide and the selective serotonin re-uptake inhibitor (SSRI), fluoxetine were examined. These compounds were also studied during chronic administration. In addition, the chronic effect of two other SSRIs $(10 \mathrm{mg} / \mathrm{kg}$ of citalopram or $3 \mathrm{mg} / \mathrm{kg}$ of paroxetine) was determined, as well as the effect of combining $1 \mathrm{mg} / \mathrm{kg}$ of $8-\mathrm{OH}-\mathrm{DPAT}$ or $1 \mathrm{mg} / \mathrm{kg}$ of WAY 100635 with $10 \mathrm{mg} / \mathrm{kg}$ of fluoxetine.

\section{METHODS}

\section{Subjects}

Ten male white Carneaux pigeons (Palmetto Pigeon Plant, Sumter, SC) were housed in individual stainless steel cages with water and crushed oyster shells continuously available, except during the experimental sessions. The pigeons were maintained at approximately $85 \%$ of their free feeding body weights by post-session supplemental feedings of Purina Pigeon Checkers (Purina Mills, St Louis, MO). All testing was conducted during the illuminated phase of the light-dark cycle (6 A.M.-6 P.M.). This study was carried out in accordance with all guidelines of the Guide for the Care and Use of Laboratory Animals (National Institutes of Health).

All of the pigeons had been trained to key peck using the method of successive approximations and were experienced on other reinforcement schedules (e.g. FRFI and progressive ratio) before the start of the present experiment. However, none of the pigeons had been tested with drugs for at least six months prior to the beginning of training for this experiment. In group one, the order of drugs tested was chlordiazepoxide, fluoxetine (chronic), alprazolam, citalopram (chronic), 8-OHDPAT (acute), WAY-100635 (acute), fluoxetine $+8-\mathrm{OH}-$ DPAT (chronic), 8-OH-DPAT (chronic), WAY100635 (chronic), fluoxetine + Way100635 (chronic), and fluoxetine (acute). A second group of five pigeons was retested with alprazolam and a third SSRI, paroxetine, to confirm the original results.

\section{Procedures}

The experiment was conducted in pigeon operant conditioning chambers (Med Associates, East Fairfield, VT) that were placed in light- and sound-attenuated enclosures equipped with ventilation fans and white noise generators. Three response keys were centered on the front panel of the operant box and could be illuminated with white, green or red lights. The reinforcement always consisted of mixed grain that was presented through an opening centered beneath the response keys. During grain presentation, this opening was illuminated and the response key lights were extinguished.

Each adjustable delay session consisted of 10 blocks of six trials (two forced and four free) and lasted for 60 min or until the schedule was completed.

Each block of trials began with the illumination of the center key. A single peck on the center key darkened this key and began the first forced trial. During the forced trials, only one of the two side keys was illuminated. The position of the key, right or left, and the color of the key, red or green, was determined randomly. If the first forced trial consisted of the presentation of the red key, then the green key was presented on the second forced trial and vice versa. These forced trials ensured that the pigeon had experience with the contingencies for both choices during that block of trials. The two forced trials were immediately followed by four free choice trials during which both of the side keys were illuminated. The positions of the red and green keys varied randomly on each trial to control for possible position preferences. A single peck on either key darkened both keys and initiated the appropriate delay period. 
The red key was always associated with a $2 \mathrm{~s}$ delay that was followed by $2 \mathrm{~s}$ of access to mixed grain. The green key was always associated with an adjustable delay that was followed by $6 \mathrm{~s}$ of access to mixed grain.

At the start of each day, the adjustable delay period (green key) was always set to $8 \mathrm{~s}$. The behavior of the pigeon during the free choice trials determined changes to the length of the adjustable delay for each succeeding block of trials. Three or four pecks on the red key, resulted in a $1 \mathrm{~s}$ decrease in the adjustable delay period, whereas three or four pecks on the green key resulted in a $1 \mathrm{~s}$ increase in the adjustable delay period. If the red and green keys were both chosen twice, no change was made to the delay period for the next block of trials. Therefore, the maximum delay that could occur on any given day was $17 \mathrm{~s}$ ( $8 \mathrm{~s}$ at the start of each day, plus a $1 \mathrm{~s}$ increase on each of the other nine blocks). However, the minimum delay that could occur was never allowed to drop below $2 \mathrm{~s}$ (equal to that of the constant delay). During the $2 \mathrm{~s}$ constant delay period, the house light remained on, whereas during the adjustable delay period, the house light pulsated on and off. Reinforcement was followed by a brief inter-trial interval (ITI) during which the house light was turned off. The ITI after the adjustable delay was always $1 \mathrm{~s}$. However, the ITI after the constant delay period was adjusted between blocks so that the length of time between successive reinforcements was the same for the two conditions.

The average length of the adjustable delay on the last five blocks of each day was recorded. Once responding on this schedule was stable (i.e. not more than $1 \mathrm{~s}$ difference in the length of the adjustable delay from one day to the next), testing with drugs (see below) was begun. For acute studies, drugs were administered on Tuesday and Friday and control data were obtained on Thursday. Although the drug was administered daily during chronic studies, the pigeons were tested in the operant chambers Monday through Friday only.

Dose response curves for acute intramuscular (i.m.) injection of alprazolam, chlordiazepoxide, fluoxetine, $8-\mathrm{OH}-$ DPAT and WAY100635 were obtained. Chronic injections of $5 \mathrm{mg} / \mathrm{kg}$ of alprazolam (5 days), $1 \mathrm{mg} / \mathrm{kg}$ of $8-\mathrm{OH}-$ DPAT (17 days), $1 \mathrm{mg} / \mathrm{kg}$ of WAY100635 (17 days), 10 $\mathrm{mg} / \mathrm{kg}$ of fluoxetine (17 days), $10 \mathrm{mg} / \mathrm{kg}$ of citalopram (17 days), and $3 \mathrm{mg} / \mathrm{kg}$ of paroxetine (17 days) were also administered. In addition, the effect of chronically combining $1 \mathrm{mg} / \mathrm{kg}$ of 8-OH-DPAT (11 days) or $1 \mathrm{mg} / \mathrm{kg}$ of WAY100635 (17 days) with $10 \mathrm{mg} / \mathrm{kg}$ of fluoxetine was also determined. The pigeons remained drug-free for at least one week (after acute dose response curves) and sometimes considerably longer (i.e. after chronic SSRI injections) while the baseline values were re-established.

\section{Statistics}

Dose response curves were obtained by averaging the data obtained from individual pigeons during the last five blocks of each day's trial. Statistical significance was determined (GraphPad Prism) using a repeated measures ANOVA followed by a Dunnett's test for comparison with the appropriate control.

During acute drug studies, drug values were compared with the appropriate control values obtained on Thursdays during the testing of that particular drug. In the case of chronic injections of drugs or drug combinations, the data from three days were averaged and then plotted. Drug and post drug control values were compared with the appropriate control value obtained immediately before each chronic study. In addition, the overall control values (water vehicle only) obtained over the course of the experiment (approximately 15 months) for each individual pigeon were calculated to obtain an indication of how the pigeons differed in their typical response (Table 1) when no drug was being administered.

\section{Drugs}

Alprazolam and chlordiazepoxide $\mathrm{HCl}$ were purchased from Sigma Chemical Co (St. Louis, MO). 8-hydroxy-(2-din-propylamino)tetralin hydrobromide (8-OH-DPAT $\mathrm{HBr}$ ) and $\mathrm{N}-\{2-[4-(2-$ methoxyphenyl)-1-piperazinyl]ethyl $\}-\mathrm{N}-(2-$ pyridinyl)cyclohexanecarboxamide (WAY-100635) were purchased from Research Biochemicals International, (Natick, MA). Fluoxetine $\mathrm{HCl}$, citalopram $\mathrm{HCl}$ and paroxetine $\mathrm{HCl}$ were provided by Eli Lilly (Indianapolis, IN). Alprazolam was dissolved in 1\% alcohol. Chlordiazepoxide, fluoxetine, citalopram, paroxetine, $8-\mathrm{OH}$ DPAT, and WAY100635 were dissolved in sterile water. All compounds and appropriate vehicles were administered into the pectoral muscle (i.m.) in a volume of 1 $\mathrm{ml} / \mathrm{kg}$ of body weight. Doses were calculated on the form indicated above. Chlordiazepoxide, alprazolam,

Table 1. Average control values for the adjustable delay period in individual pigeons

\begin{tabular}{lc}
\hline Pigeon & Delay to Reward (sec) \\
\hline 8698 & $7.2( \pm 0.4)$ \\
9018 & $6.9( \pm 0.4)$ \\
1053 & $2.2( \pm 0.02)$ \\
4363 & $5.3( \pm 0.4)$ \\
6095 & $4.7( \pm 0.3)$ \\
6508 & $7.6( \pm 0.6)$ \\
6083 & $8.9( \pm 0.7)$ \\
1098 & $8.7( \pm 0.7)$ \\
5330 & $7.7( \pm 0.5)$ \\
1147 & $6.4( \pm 0.3)$ \\
\hline
\end{tabular}

Each value is the average of the control values obtained throughout the period of these experiments ( \pm standard error). For pigeons \#8698, $\# 9018, \# 1053, \# 4363$, and \#6095 the number of vehicle control injections was 34. For \#6508, \#6083, \#1098, \#5330, and \#1147 the number of vehicle injections was 12 . 
8-OH-DPAT and WAY100635 were injected $20 \mathrm{~min}$ before the test session. Fluoxetine, citalopram and paroxetine were injected $1 \mathrm{~h}$ before the test session. When used in combination with 8-OH-DPAT or WAY100635, fluoxetine was injected $45 \mathrm{~min}$ prior to $8-\mathrm{OH}$-DPAT or WAY100635.

\section{RESULTS}

Each pigeon was given at least 14 days of training on the present schedule before any control data were obtained or drug injections were administered. Although there were considerable individual differences in the delay tolerated before the larger reinforcement, the average lengths of the adjustable delay periods for individual animals remained stable throughout the experiment (Table 1). After each compound was tested, the vehicle baseline was re-established. The baseline showed no consistent tendency to drift up or down during the course of the experiments (Figure 1).

\section{Anxiolytic Administration}

Alprazolam induced a dose-related reduction in the adjustable delay period (Figure 2), with a maximum decrease of approximately $3 \mathrm{~s}$ at the highest dose tested $\left(\mathrm{F}_{3,12}=3.53 ; p=.05\right)$. Likewise both the 1 and the 10 $\mathrm{mg} / \mathrm{kg}$ doses of chlordiazepoxide decreased the average adjustable delay period. At $1 \mathrm{mg} / \mathrm{kg}$ of chlordiazepoxide the decrease was approximately $2 \mathrm{~s}$ (vehicle: $6.5( \pm 1.2) \mathrm{sec} ; 1 \mathrm{mg} / \mathrm{kg}: 4.4$ ( \pm 0.5$) \mathrm{sec}$ ). However, at 10 $\mathrm{mg} / \mathrm{kg}$ of chlordiazepoxide, one pigeon (\#9018) in-

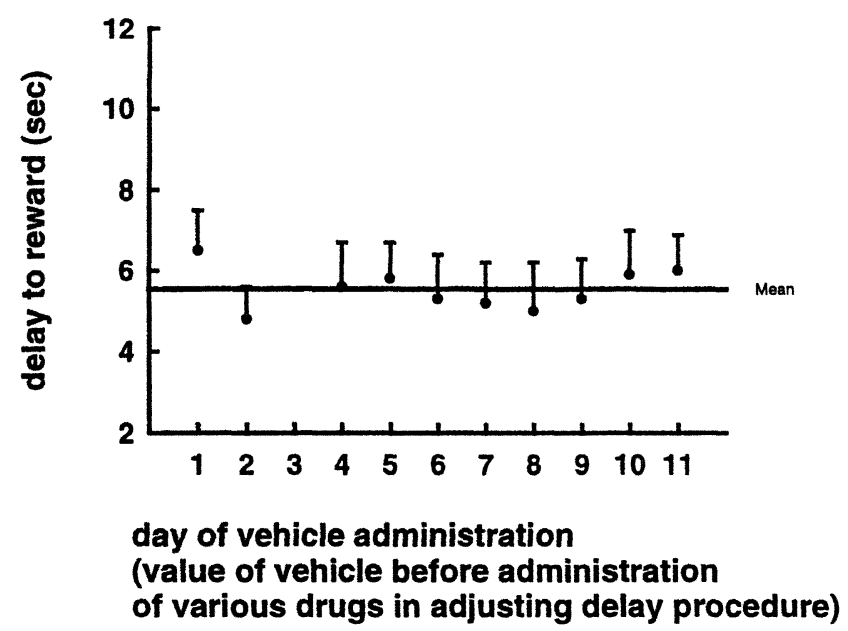

Figure 1. The average length of delay to reinforcement during vehicle control trials in group 1 . The values plotted are the control values before each of the 11 drug tests. Note that value 3 (vehicle control before alprazolam) is not included because the vehicle included a slight amount of alcohol.

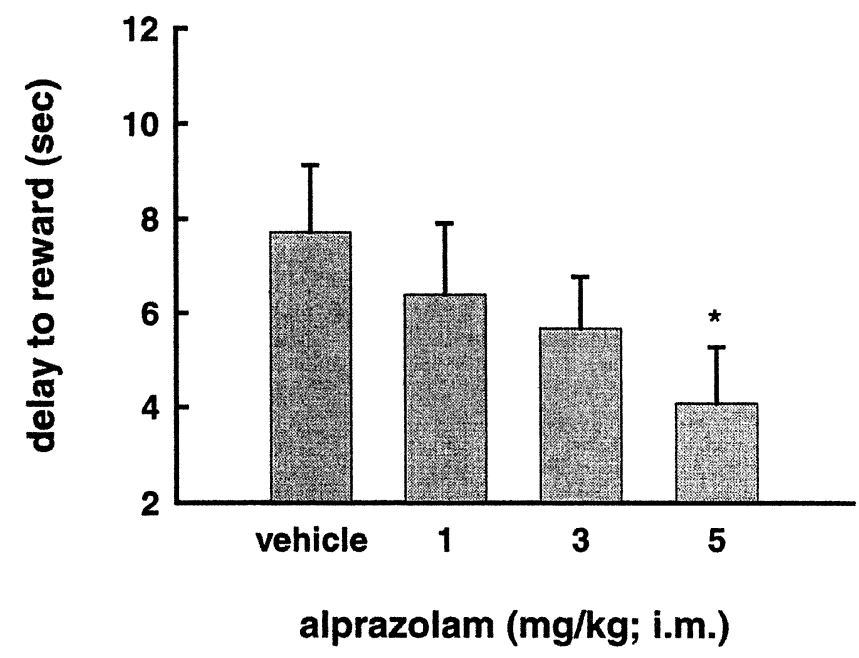

Figure 2. The average length of delay to the reinforcement during the last five blocks of trials after acute i.m. administration of alprazolam $20 \mathrm{~min}$. before the daily session. $\mathrm{n}=5$. Bars indicate standard errors. " Dunnett's $p<.05$

creased (by $2.6 \mathrm{~s}$ ), rather than decreased, the length of the adjustable delay period (Figure 3 ). The other four birds exhibited decreases averaging $3.3( \pm 0.3)$ sec. Administration of $5 \mathrm{mg} / \mathrm{kg}$ of alprazolam per day for five consecutive days resulted in a decrease in the length of the adjustable delay period (Figure 4; repeated measure ANOVA $\mathrm{F}_{6,18}=3.7 ; p=.014$ ) which returned to control values upon cessation of drug administration. One pigeon was omitted from the analysis (original group size: $n=5$ ) because he failed to key-peck for the first three days of administration of $5 \mathrm{mg} / \mathrm{kg}$ of alprazolam. Clearly, this dose was too high for that bird.

Acute administration of fluoxetine at doses between 0.3 and $10 \mathrm{mg} / \mathrm{kg}$ had no effect on the average length of the adjustable delay period (Figure 5; repeated measure

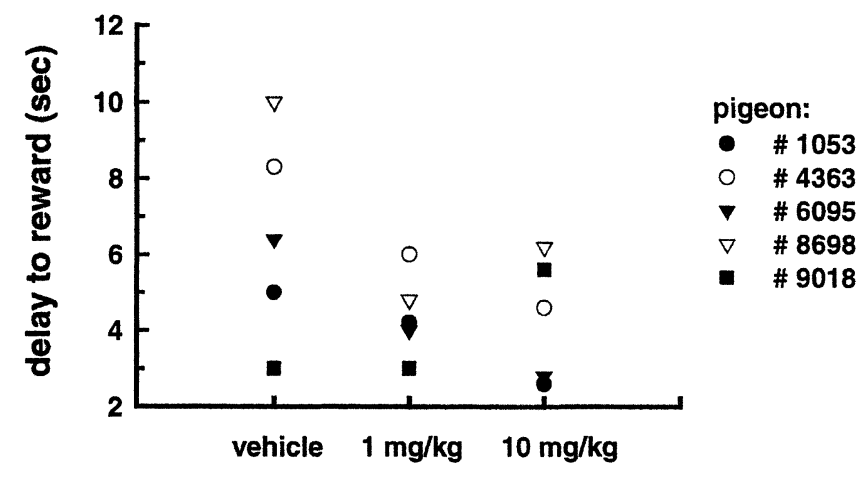

chlordiazepoxide (i.m.)

Figure 3. The effect of administering $1 \mathrm{mg} / \mathrm{kg}$ or $10 \mathrm{mg} / \mathrm{kg}$ of chlordiazepoxide to individual pigeons. 


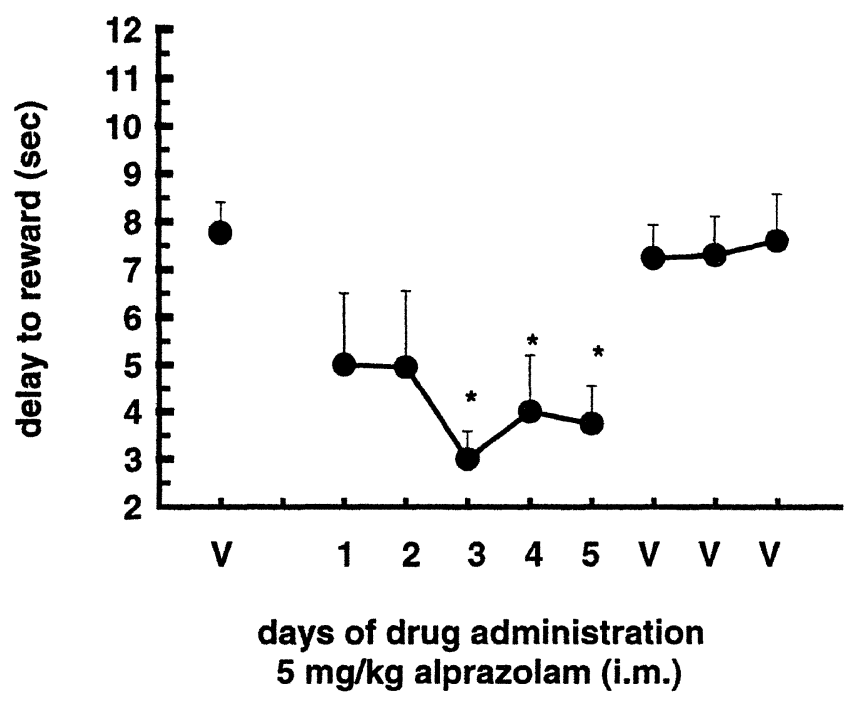

Figure 4. The effect of administering $5 \mathrm{mg} / \mathrm{kg}$ (i.m.) of alprazolam $20 \mathrm{~min}$. before the test session on five consecutive days. $\mathrm{V}=$ vehicle (i.e. $1 \%$ ethanol) injection on three consecutive days after cessation of drug administration. The data points are group averages of the length of delay during the last five blocks of trials of each day's test. $n=4$. Bars indicate S.E.M. ${ }^{*}$ Dunnett's $p<.05$

ANOVA $\left.\mathrm{F}_{4,16}=0.58\right)$. However, the chronic administration of fluoxetine $(10 \mathrm{mg} / \mathrm{kg})$ or citalopram $(10 \mathrm{mg} / \mathrm{kg})$ resulted in gradual increases in the length of the adjustable delay period (Figure 6; repeated measure ANOVA: citalopram $\mathrm{F}_{7,28}=2.58 ; p=.04$; fluoxetine $\mathrm{F}_{10,40}=1.9$; $p=.07)$. Likewise, in a second group of pigeons, chronic administration of paroxetine $(3 \mathrm{mg} / \mathrm{kg})$ also gradually increased the length of the adjustable delay period $\left(\mathrm{F}_{6,24}=2.26 ; p=.07\right.$; Figure 6$)$. The adjustable delay period after vehicle differed for the two groups of

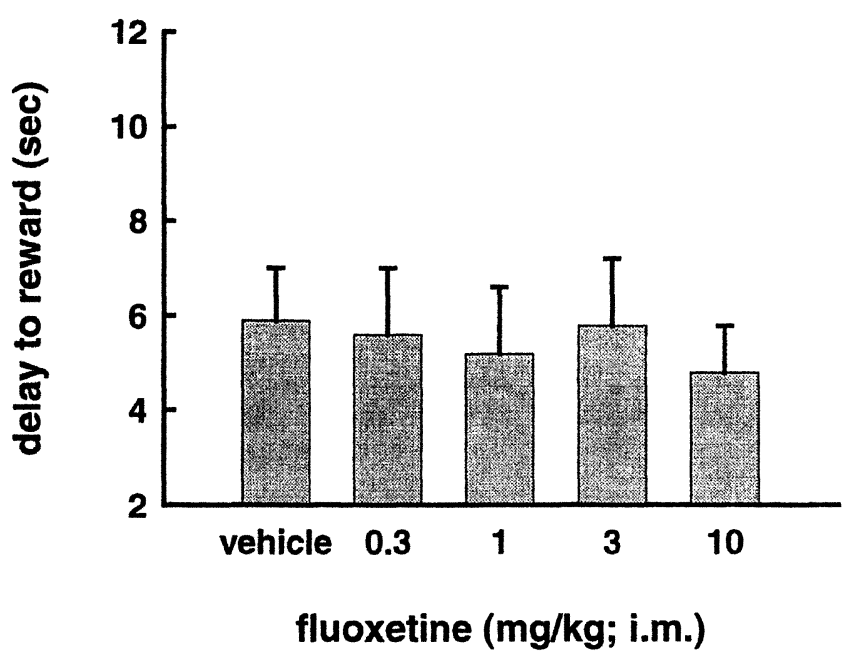

Figure 5. The average number of seconds from response to reward after acute i.m. administration of fluoxetine $1 \mathrm{~h}$ before the daily session. Bars indicate standard errors. $\mathrm{n}=5$

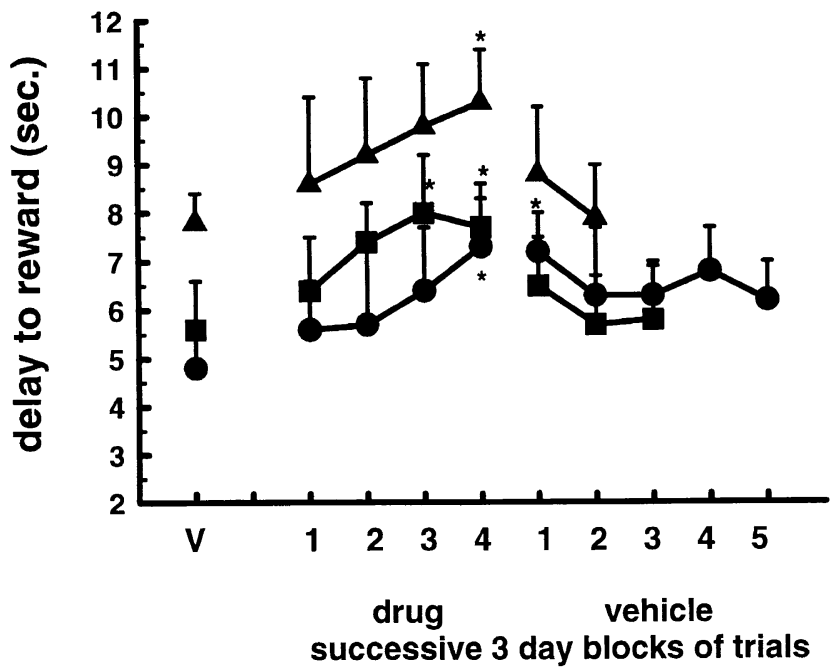

Figure 6. Average number of seconds from response to reward. Each point on the $X$ axis represents the average of three days of results. Fluoxetine $(10 \mathrm{mg} / \mathrm{kg}, \mathrm{i} . \mathrm{m}$.), citalopram $(10 \mathrm{mg} / \mathrm{kg}$, i.m.) and paroxetine $(3 \mathrm{mg} / \mathrm{kg}$, i.m.) were each administered $1 \mathrm{~h}$ prior to each day's session. Vehicle administration was given in a like manner following cessation of the drug. $\mathrm{V}=$ vehicle. Bars represent S.E.M. $\mathrm{n}=5$ /group. ${ }^{*}$ Dunnett's test $p<.05$

pigeons (fluoxetine/citalopram group: $4.8 \pm 0.8 \mathrm{~s}$ before fluoxetine and $5.6 \pm 1$ s before citalopram; paroxetine group: $7.8 \pm 0.6 \mathrm{~s}$ before paroxetine). Despite this difference, the increase in the adjustable delay over the course of the chronic administration of SSRI was approximately $2 \mathrm{~s}$ in each case. The length of delay until reinforcement increased significantly during the last three days of drug administration (Dunnett's comparison with control $p<.05$ for each compound) and gradually returned to baseline values after cessation of each drug. However, it took considerably longer for the baseline to return to pre-drug levels following cessation of fluoxetine than following cessation of either citalopram or paroxetine. In fact, the first three days of vehicle administration following the cessation of fluoxetine were still significantly different from the value obtained just prior to beginning fluoxetine administration (Dunnett's $p<.05$ ).

Acute injections of either 8-OH-DPAT or WAY100635 did not consistently affect the length of the adjustable delay period (Table 2). After administration of $1 \mathrm{mg} / \mathrm{kg}$ of 8-OH-DPAT the scores of 2 pigeons increased (250 and $150 \%$ of control), whereas the scores of the other three pigeons were unchanged or decreased $(93,94$ and $79 \%$ of control). After administration of $1 \mathrm{mg} / \mathrm{kg}$ of WAY 
Table 2. Effect of acute administration of increasing doses of 8-OH-DPAT or WAY100635 on the average value of length of delay in seconds to the larger reinforcement in the last 5 blocks of trials of each day's session

\begin{tabular}{lc}
\hline Drug & Delay to Larger Reward (sec) \\
\hline Vehicle & $5.26( \pm 0.9)$ \\
$8-O H-D P A T$ & $4.96( \pm 1.18)$ \\
$0.03 \mathrm{mg} / \mathrm{kg}$ & $4.28( \pm 0.77)$ \\
$0.1 \mathrm{mg} / \mathrm{kg}$ & $5.82( \pm 1.37)$ \\
$0.3 \mathrm{mg} / \mathrm{kg}$ & $6.78( \pm 1.52)$ \\
$1 \mathrm{mg} / \mathrm{kg}$ & \\
WAY100635 & $5( \pm 1.1)$ \\
$0.3 \mathrm{mg} / \mathrm{kg}$ & $6.12( \pm 1.13)$ \\
$1 \mathrm{mg} / \mathrm{kg}$ & \\
\hline
\end{tabular}

The number in parenthesis is the standard error.

the scores ranged between 135 and $78 \%$ of the control values.

Daily administration of $1 \mathrm{mg} / \mathrm{kg}$ of 8-OH-DPAT did not significantly affect the length of the adjustable delay (Figure 7). However, administration of a combination of $10 \mathrm{mg} / \mathrm{kg}$ of fluoxetine plus $1 \mathrm{mg} / \mathrm{kg}$ of $8-\mathrm{OH}-\mathrm{DPAT}$ increased the adjustable delay periods within the first three days of administration (Figure 7; repeated measure ANOVA $\mathrm{F}_{7,28}=3.63 ; p=.007$ ). After administration of the drug combination, the length of the adjustable delay period after three days was similar to that obtained after nine days of administration of the same dose of fluoxetine by itself. The length of the average adjustable period returned to control values over the

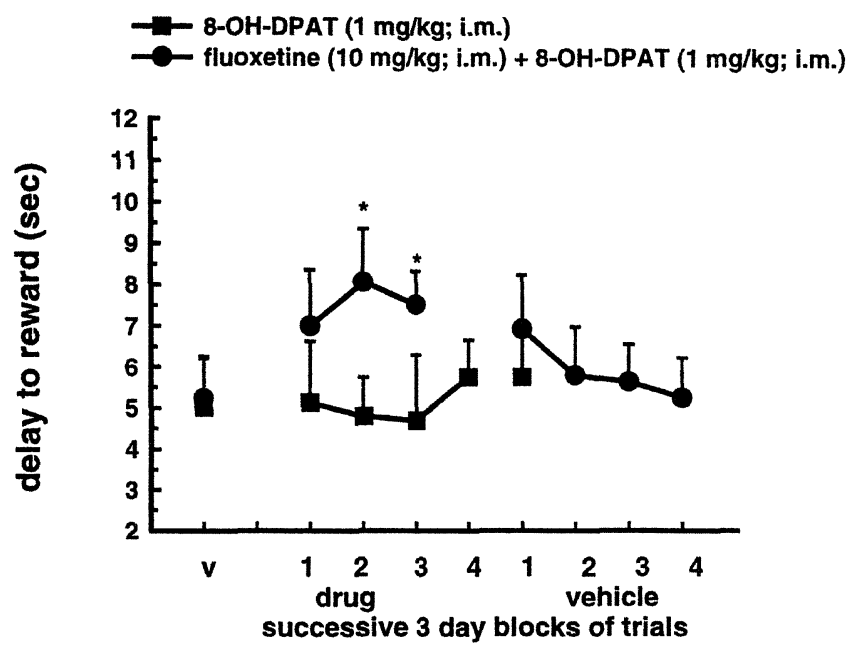

Figure 7. Average number of seconds from response to reward. Each point on the $X$ axis represents the average of three days of results. 8-OH-DPAT ( $1 \mathrm{mg} / \mathrm{kg}$, i.m.) was administered $20 \mathrm{~min}$. before the test session. When administered in combination, $10 \mathrm{mg} / \mathrm{kg}$ of fluoxetine was administered $45 \mathrm{~min}$ prior to $1 \mathrm{mg} / \mathrm{kg}$ of $8-\mathrm{OH}-\mathrm{DPAT}$. $\mathrm{V}=$ Vehicle. Vehicle administration was given on consecutive days following cessation of drug. Bars represent S.E.M. * Dunnett's $p<.05 . \mathrm{n}=5$ first few days after cessation of administration of the drug combination.

Daily administration of $1 \mathrm{mg} / \mathrm{kg}$ of WAY100635 by itself did not significantly increase the average length of the adjustable delay period (repeated measure ANOVA $\mathrm{F}_{5,20}=1.3$; Figure 8). When used in combination with 10 $\mathrm{mg} / \mathrm{kg}$ of fluoxetine, $1 \mathrm{mg} / \mathrm{kg}$ of WAY100635 did not increase the average length of adjustable delay period (repeated measure ANOVA $F_{6,18}=2.13$ ).

\section{DISCUSSION}

The pigeons were required to choose between a small immediate reward and a larger delayed reward. Choice of the small reward decreased the delay to the larger reinforcement, whereas choice of the larger reward increased the delay. The average length of the delay on the last five blocks of daily trials provided an estimate of the pigeons' capacity to wait for a delayed reward. If one accepts the operational definition of 'impulsiveness' as a preference for a small immediate reward over a larger delayed reward, then a relatively low value of the average length of delay at the end of the day's session may signify 'impulsiveness'. In contrast, a relatively high value may indicate relative 'self control'. The major finding of this study are that acute administration of benzodiazepine anxiolytics decreases the de-

- fluoxetine $(10 \mathrm{mg} / \mathrm{kg}$, i.m. $)+$ WAY100635 (1 mg/kg)
WAY100635 (1 mg/kg, i.m.)

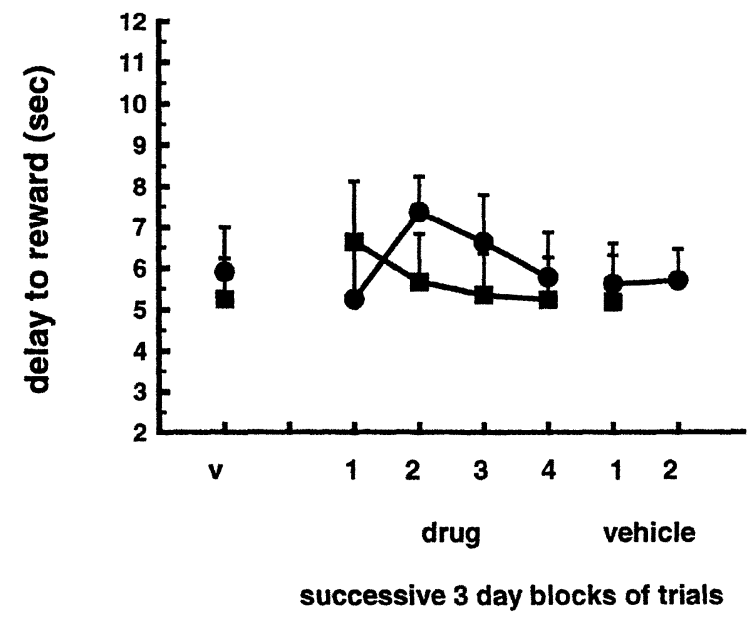

Figure 8. Average number of seconds from response to reward. Each point on the $X$ axis represents the average of three days of results. WAY100635 (1 mg/ kg, i.m.) was administered $20 \mathrm{~min}$. before the test session $(n=5)$. When administered in combination, $10 \mathrm{mg} / \mathrm{kg}$ of fluoxetine was administered 45 min prior to $1 \mathrm{mg} / \mathrm{kg}$ of WAY100635 ( $\mathrm{n}=4)$. Vehicle administration was given on consecutive days following cessation of drug. Bars represent S.E.M. 
lay interval, (i.e. the animals were more "impulsive"), whereas chronic, but not acute, administration of SSRIs increases the delay interval (i.e. the animals become less "impulsive," more "self controlled").

It should be reiterated that each of these pigeons had been tested using different experimental paradigms (e.g. progressive ratio, fixed ratio/fixed interval schedules) before the beginning of the present study. The exact procedures and drugs tested differed between animals. This was followed by an extensive drug-free interval (minimum six months) to eliminate "neurochemical carryover" between studies. Although there were considerable individual differences in baseline performance, each pigeon's control behavior remained consistent throughout the course of the experiment. Despite these differences, the baseline behavior could be consistently increased, decreased, or not affected dependent upon the class of drug administered. Great care was taken to ensure that baseline performance was re-established between each drug test. The major findings (i.e. decrease in delay to larger reinforcement using a benzodiazepine, and an increase in the delay using a third SSRI, paroxetine) were replicated in a second group of pigeons.

Benzodiazepines have been reported to decrease tolerance of reward delay in rats (Thiebot et al. 1985) although some discrepancies have been reported with respect to alprazolam (Bizot et al. 1999). Furthermore, chronic benzodiazepine use increased aggressive, violent, and impulsive behavior in some patients (Mathew et al. 2000; Gardner and Cowdry 1985). In the present study, $5 \mathrm{mg} / \mathrm{kg}$ of alprazolam decreased the average length of delay to the larger reinforcement. This decrease was maintained over a period of five days of drug administration but promptly returned to the predrug control values upon cessation of alprazolam administration. These data are consistent with the suggestion that benzodiazepines increase impulsive behavior by dampening the serotonergic system (Thiebot et al. 1985). Benzodiazepines reportedly decrease 5-HT turnover (Saner and Pletscher 1979), decrease the firing rate of 5-HT neurons (Trulson et al. 1982), and reduce the amount of 5-HT released from nerve endings (Soubrie et al. 1983). Lesions of the 5-HT system that result in a depletion of 5-HT also reduce the ability of a rat to wait for a delayed reward (Wogar et al. 1993; Richards and Seiden 1995). A 5-HT synthesis inhibitor, para-chlorophenylalanine, induced a shift toward an immediate reward in the rat (Bizot et al. 1999). The net decrease in 5-HT neurotransmission may be responsible for the shift toward more impulsive behavior.

In the current study, chronic, but not acute, administration of fluoxetine, citalopram or paroxetine increased the delay to the larger reinforcement. In other operant paradigms that were designed to study the ability of an animal to wait for reinforcement (Evenden and Ryan
1996; Charrier and Thiebot 1996), acute administration of SSRIs was also ineffective. However in the T-maze, acute administration of SSRIs was sufficient to increase the number of choices of a large delayed reward (Bizot et al. 1988; Thiebot et al. 1985).

The gradual onset of SSRI activity obtained in the present series of experiments is somewhat analogous to the gradual onset of the therapeutic activity of SSRIs in depression. Acutely, SSRIs depress 5-HT neurotransmission because increased stimulation of 5-HT autoreceptors decreases the firing of 5-HT neurons (Blier and de Montigny 1983). The onset of SSRI therapeutic activity seems to correspond with the desensitization of the $5-\mathrm{HT}_{1 \mathrm{~A}}$ autoreceptor with the consequent recovery of firing of the 5-HT neuron and elevation of extracellular 5-HT in the serotonergic projection areas of the CNS. Thus, the gradual shift toward longer delays to reward (i.e. less impulsive behavior) may be due to the gradual net increase in 5-HT neurotransmission.

In theory, if one were to block activation of the $5-\mathrm{HT}_{1 \mathrm{~A}}$ autoreceptor while administering a SSRI, enhanced 5-HT neurotransmission should occur more quickly. In fact, clinical results indicate that administration of pindolol, a partial agonist at the $5 \mathrm{HT}_{1 \mathrm{~A}}$ receptor, in conjunction with a SSRI accelerated the antidepressant effect of the SSRI (Artigas et al. 1994; Blier and Bergeron 1995). However, the results of the present experiment demonstrated that administration of WAY100635 in addition to fluoxetine ultimately blocked the effect of chronic fluoxetine. By blocking the presysnaptic 5- $\mathrm{HT}_{1 \mathrm{~A}}$ receptor, WAY100635 potentiates increased 5-HT induced by SSRIs (Hjorth et al. 1997). Because WAY100635 is a full $5-\mathrm{HT}_{1 \mathrm{~A}}$ receptor antagonist (Fletcher et al. 1996), it blocks activity at both presynaptic and postsynaptic $5-\mathrm{HT}_{1 \mathrm{~A}}$ receptors. However, $5-\mathrm{HT}_{1 \mathrm{~A}}$ receptor agonists are thought to have important anxiolytic and antidepressive properties (review: De Vry 1995). Inhibiting activity at the $5-\mathrm{HT}_{1 \mathrm{~A}}$ postsynaptic receptors could reduce some of the beneficial effects of increased extracellular 5-HT. That appears to be what has happened in the present case. Activity at the postsynaptic $5-\mathrm{HT}_{1 \mathrm{~A}}$ receptor may be necessary in order to increase the length of time the pigeon will wait to get the larger reinforcement (i.e. to decrease 'impulsive behavior'). It is noteworthy in this regard that pindolol is not a full antagonist (Clifford et al. 1998) at 5- $\mathrm{HT}_{1 \mathrm{~A}}$ receptors and thus would not totally block $5-\mathrm{HT}_{1 \mathrm{~A}}$ function.

The results obtained in the present study when a $5-\mathrm{HT}_{1 \mathrm{~A}}$ receptor agonist was combined with fluoxetine provided further support for the idea that postsynaptic $5-\mathrm{HT}_{1 \mathrm{~A}}$ receptor activity is involved in the control of impulsive behavior. The onset of activity (number of trials to significantly increase delay to the larger reward) was sooner after administration of a $5-\mathrm{HT}_{1 \mathrm{~A}}$ receptor agonist (8-OH-DPAT) in addition to fluoxetine than when fluoxetine had been administered by itself. Possibly, the addition of a $5-\mathrm{HT}_{1 \mathrm{~A}}$ receptor agonist amplified the de- 
sensitization of the $5-\mathrm{HT}_{1 \mathrm{~A}}$ presynaptic receptor and more quickly normalized 5-HT neuronal firing. Thus, as well as increased overall 5-HT neurotransmission, the activity of the postsynaptic $5-\mathrm{HT}_{1 \mathrm{~A}}$ receptor also would be enhanced. $5-\mathrm{HT}_{1 \mathrm{~A}}$ receptor partial agonists, such as buspirone, have been demonstrated to augment the antidepressant effect of SSRIs in a clinical setting (Dimitriou and Dimitriou 1998) .

Although the results strongly suggest that postysnaptic $5-\mathrm{HT}_{1 \mathrm{~A}}$ receptor activity is necessary, neither acute administration of increasing doses of $8-\mathrm{OH}-$ DPAT nor chronic administration of $1 \mathrm{mg} / \mathrm{kg}$ of $8-\mathrm{OH}-$ DPAT (without additional fluoxetine) was effective in modifying the delay interval. In other delay of reward paradigms, the results obtained with 8-OH-DPAT have been variable. Evenden and Ryan (1999) found that after administration of a $5-\mathrm{HT}_{1 \mathrm{~A}}$ receptor agonist $(8-\mathrm{OH}-$ DPAT), the rat seemed to become indifferent to reinforcement size or delay. Poulos et al. (1996) found that 8-OH-DPAT had a biphasic effect. Low doses (0.006$0.03 \mathrm{mg} / \mathrm{kg}$ ) of $8-\mathrm{OH}$-DPAT increased the choice of an immediate reinforcer, whereas a higher dose (0.06) increased the choice of a delayed reward. Bizot et al. (1999) found that 8-OH-DPAT increased the choice of a larger delayed reward, but this effect was not antagonized by WAY100635. Thus, it would seem that although activity at the $5-\mathrm{HT}_{1 \mathrm{~A}}$ postsynaptic receptor may be necessary, it is an insufficient condition for reducing 'impulsive' behavior. The fact that WAY100635 had no significant effect on the length of the delay to reinforcement and seemed to suppress the effect of chronic fluoxetine supports this conclusion. Others also have reported that WAY100635 was either ineffective in delay of reward paradigms (Evenden and Ryan 1999), or, at a very large dose $(4 \mathrm{mg} / \mathrm{kg})$, reduced the number of choices of the large reward (Bizot et al. 1999).

In summary, the paradigm described in this report may provide a useful method for studying the efficacy of new compounds in the treatment of impulsive disorders. The present results provide further evidence that SSRIs decrease impulsive behavior in a variety of species and suggest that intact functioning of $5-\mathrm{HT}_{1 \mathrm{~A}}$ receptors may be important in this regard. Furthermore, these results suggest that the combination of a $5-\mathrm{HT}_{1 \mathrm{~A}}$ receptor agonist with a SSRI may hasten the onset of therapeutic activity of the SSRI.

\section{REFERENCES}

Ainslie GW (1974): Impulse control in pigeons. J Exp Anal Behav 21:481-485

Artigas F, Perez V, Alvarez E (1994): Pindolol induces a rapid improvement of depressed patients with serotonin reuptake inhibitors. Arch Gen Psychiatry 51:248-251

Bizot JC, Bihan CL, Puech AJ, Hamon M, Thiebot MH (1999):
Serotonin and tolerance to delay of reward in rats. Psychopharmacology (Berl) 146:400-412

Bizot JC, Thiebot MH, Bihan CL, Soubrie P, Simon P (1988): Effects of imipramine-like drugs and serotonin uptake blockers on delay of reward in rats. Possible implication in the behavioral mechanism of action of antidepressants. J Pharmacol Exp Ther 246:1144-1151

Blier P, Bergeron R (1995): Effectiveness of pindolol with selected antidepressant drugs in the treatment of major depression. J Clin Psychopharmacol 15:217-222

Blier P, de Montigny C (1983): Electrophysiological studies on the effect of repeated zimelidine administration on serotonergic neurotransmission in the rat. J Neurosci 3:1270-1278

Brunner D, Hen R (1997): Insights into the neurobiology of impulsive behavior from serotonin knockout mice. Ann NY Acad Sc 836:81-105

Charrier D, Thiebot MH (1996): Effects of psychotropic drugs on rat responding in an operant paradigm involving choice between delayed reinforcers. Pharmacol Biochem Behav 54:149-157

Clifford EM, Gartside SE, Umbers V, Cowen PJ, Hajos M, Sharp T (1998): Electrophysiological and neurochemical evidence that pindolol has agonist properties at the $5-\mathrm{HT}_{1 \mathrm{~A}}$ autoreceptor in vivo. Br J Pharmacol 124:206212

De Vry J (1995): 5- $\mathrm{HT}_{1 \mathrm{~A}}$ receptor agonists: recent developments and controversial issues. Psychopharmacology (Berl) 121:1-26

Dimitriou EC, Dimitriou CE (1998): Buspirone augmentation of antidepressant therapy. J Clin Psychopharm 18:465-469

Evenden JL (1999): Varieties of impulsivity. Psychopharmacology (Berl) 146:348-361

Evenden JL, Ryan CN (1996): The pharmacology of impulsive behaviour in rats: the effects of drugs on response choice with varying delays of reinforcement. Psychopharmacology (Berl) 128:161-170

Evenden JL, Ryan CN (1999): The pharmacology of impulsive behaviour in rats. VI: the effects of ethanol and selective serotonergic drugs on response choice with varying delays of reinforcement. Psychopharmacology (Berl) 146:413-421

Fletcher A, Forster EA, Bill DJ, Brown G, Cliffe IA, Hartley JE, Jones DE, McLenachan A, Stanhope KJ, Crichley DJP, Childs KJ, Middlefell VC, Lanfumey L, Corradetti R, Laporte AM, Gozlan H, Hamon M, Dourish CT (1996): Electrophysiological, biochemical, neurohormonal and behavioural studies with WAY-100636, a potent, selective and silent $5-\mathrm{HT}_{1 \mathrm{~A}}$ receptor antagonist. Behav Brain Res 73:337-353

Gardner DL, Cowdry RW (1985): Alprazolam-induced dyscontrol in borderline personality disorder. Am J Psychiatry 142:98-100

Hjorth S, Westlin D, Bengtsson HJ (1997): WAY100635 augmentation of the 5-HT-elevating action of citalopram: relative importance of the dose of the 5-HT1A (Auto)receptor blocker versus that of the 5-HT reuptake inhibitor. Neuropharmacology 36:461-465

Kavoussi RJ, Liu J, Coccaro EF (1994): An open trial of sertraline in personality disordered patients with impulsive aggression. J Clin Psychiatry 55:137-141 
Linnoila M, Virkkunen M, Scheinin M, Nuutila A, Rimon R, Goodwin FK (1983): Low cerebrospinal fluid 5-hydroxyindolacetic acid concentration differentiates impulsive from non-impulsive violent behavior. Life Sci 11:665-709

Logue AW (1988): Research on self-control: An integrating framework. Behav Brain Sci 11:665-709

Mathew VM, Dursun SM, Reveley MA (2000): Increased aggressive, violent and impulsive behaviour in patients during chronic-prolonged benzodiazepine use. Can J Psychiatry 45:89-90

Mazur JE (1984): Tests of an equivalence rule for fixed and variable reinforcer delays. J Exp Psychol 10:426-436

Mazur JE (1995): Conditioned reinforcement and choice with delayed and uncertain primary reinforcers. J Exp Anal Behav 63:139-150

Poulos CX, Parker JL, Le AD (1996): Dexfenfluramine and 8-OH-DPAT modulate impulsivity in a delay-of-reward paradigm: implications for a correspondence with alcohol consumption. Behav Pharmacol 7:395-399

Richards JB, Seiden LS (1995): Serotonin depletion increases impulsive behavior in rats. Soc Neurosci Abstr 21:1693

Roy A, Adinoff B, Linoila M (1988): Acting out hostility in normal volunteers: negative correlation with CSF 5-HIAA levels. Psychiatry Res 24:187-194

Saner A, Pletscher A (1979): Effects of diazepam on cerebral 5-hydroxytryptamine synthesis. Eur J Pharmacol 55:315-318

Soubrie P (1986): Reconciling the role of central serotonin neurons in human and animal behavior. Behav Brain Sc 9:319-364

Soubrie P, Blas C, Ferron A, Glowinski J (1983): Chlordiazepoxide reduces in vivo serotonin release in the basal ganglia of 'encephale isole' but not of anaesthetized cats: evidence for a dorsal raphe site of action. J Pharmacol Exp Ther 226:526-532

Thiebot MH, Bihan CL, Soubrie P, Simon P (1985): Benzodiazepines reduce the tolerance to reward delay in rats. Psychopharmacology (Berl) 86:147-152

Trulson ME, Preussler DW, Howell GA, Frederickson CJ (1982): Raphe unit acitivity in freely moving cats: effects of benzodiazepines. Neuropharmacology 21:1050-1082

Wogar MA, Bradshaw CM, Szabadi E (1993): Effects of lesions of the ascending 5-hydroxytraptaminergic pathways on choice between delayed reinforcers. Psychopharmacology (Berl) 111:239-243 